\title{
Transforming Values into Behaviors: A Study on the Application of Values Education to Families in Turkey
}

\author{
Deniz Tonga $^{1}$ \\ ${ }^{1}$ Social Studies Education, Education Faculty, Kırıkkale University, Kırıkkale, Turkey \\ Correspondence: Deniz Tonga, Social Studies Education, Education Faculty, Kirıkale University, 71450, \\ Kırıkkale, Turkey. Tel: 90-318-3574242-1328. E-mail: deniztonga@hotmail.com
}

Received: February 8, 2016

Accepted: February 18, $2016 \quad$ Online Published: March 6, 2016

doi:10.5539/jel.v5n2p24

URL: http://dx.doi.org/10.5539/jel.v5n2p24

\begin{abstract}
No matter what century we live in, even though the tools we use change from age to age, man is not a creature who can be considered or understood without the concept of values. Although we have different religions, languages, races and cultures, the personality of man is always constructed through values. Values are factors that directly influences human life and society in a positive or negative way. This study suggests that values education aimed at teaching individuals certain values is not sufficiently practiced by families in Turkey. In order to address the problem, this study aimed to increase the awareness of family members regarding values and help them turn values into behavior in everyday life. To this end, a 24-month "values education program" involving a set of activities was carried out. Every month, a specific value was chosen taking into account the needs of family members and "value booklets" were prepared using four sub-dimensions of the chosen value. 10 families participated in the program and the data was collected from 25 individuals. The resulting data was subjected to content analysis. 3 main themes were found to be important in the light of the data: moral development, development of communication skills, and religiousness. These themes were thought to be beneficial in terms of understanding the effectiveness and importance of family members' internalizing values and turning them into behavior in everyday life.
\end{abstract}

Keywords: value, values education, behavior, values education in family, Turkey

\section{Introduction}

Today, economic, technological and scientific developments occur at ever greater pace. We live in a world where various problems emerge with these developments. Poverty, unemployment, violence, racism and gender inequality are considered to be major concerns and problems of the 21 st century by educators and politicians (Holden, 2000). Among significant educational concerns in any society, the issue of preparing the coming generations morally to ensure a positive future is as important as individual and social welfare and providing all members of the society with access to resources. The relationship between students, families and society in general may be improved by giving more importance to this issue. The relationship between schools, families and society may provide various opportunities for promoting values such as personal development, democratic participation and economic development (Aspin, 2007).

Children are affected by social problems, violence and intolerance and negative habits. Educators share the opinion that solving these problems that threaten the social order and disrupt the peacefulness of a society is possible with an effective values education (Deveci \& Selanik Ay, 2009). The tendency to address the concept of value in educational research has been increasing with constantly, while there has also been an increase in the number of studies in the literature on values education in different disciplines (Bills \& Husbands, 2005; Lovat \& Clement, 2008; Thomson \& Bernhardt, 2010; Webster, 2010; Moosmayer \& Siems, 2012; Law, 2013; Thornberg \& Oğuz, 2013; Sundström \& Wolming, 2014; Choo, 2015).

With the inclusion of values education in educational programs in Turkey since the early 2000s, there has been a significant increase in the number of studies on values education. When we examine the research on values and values education under their main categories, these can be classified as institutional articles (Kulaksızoğlu \& Dilmaç, 2000; Yazıc1, 2006; Yeşil \& Aydın, 2007; Akbaş, 2008; Cihan, 2014); opinions of teachers about values and values education (Yılmaz, 2007; Cerit, 2008; Altınkurt \& Yılmaz, 2010; Balcı \& Yanpar Yelken, 2010; Çiftçi \& Eser Ünald1, 2014); opinions of students and prospective teachers about values and value education (Fidan, 
2009; Yazar, 2012; Gömleksiz \& Cüro, 2011; Oğuz, 2012; Aladağ \& Kuzgun, 2015); values in textbooks and the curriculum (Kabapınar, 2007; Yaman \& Çolak, 2009; Özkan, 2010; Tonga \& Uslu, 2015); and the opinions of families about values (Keskin \& Yapıc1, 2008; Tay \& Yıldırım, 2009; Balcı \& Yanpar Yelken, 2013; Kuş, Karatekin, \& Merey, 2015). However, while there are certain studies - generally short-term -in the literature aimed at teaching values to students (Demirhan İşçan \& Senemoğlu, 2009; Tahiroğlu, Yıldırım, \& Çetin, 2010), we were not able to find a long-term application study on values education in the family.

This study aims to carry out a variety of activities in families in order to help individuals transfer universal human values into everyday life and then evaluate the results of these activities. Rather than seeking the opinions of participants on values, this study focuses on creating an awareness related to how values can be applied. The reason for taking the opinions of participants on values is to explore and figure out how values turn into behavior. In other words, this study tries to encourage and to raise awareness in families of how to transfer values into everyday life within the framework of values education.

I thus believe that this study will contribute to the values education given in schools. I advocate the active participation of families in values education and assert that giving values education within the family will contribute to educating individuals with the values desired. In addition, I believe that the present study will contribute to the literature considering the current absence of an adequate and long-term values education program, in which families can participate actively and as a family.

This study was conducted in a region in Turkey where the majority of the population is Turkish Muslims. However, the study may also be carried out in Europe or America with individuals with different religions and ethnic identities, as the values involved are generally regarded as universal. Therefore, this study may also be carried out in the Far East, Europe or America with Christians, Jews or individuals with various other religious beliefs. I believe that this potential diversity of the areas of application and the direct participation of families in values education add significance to this study.

\subsection{Values Education and the Individual}

Individuals grow up with various values regardless of their nationality, culture or religion. In fact, this is the very nature of how an individual is socialized (Kağıtçıbaşı, 2010). Each individual, in a sense, is the fruit or product of his or her environment (Duru, 1975). In other words, individuals are greatly influenced by their environment (Moreland \& Levine, 1982; Kağıtçıbaş1, 2010). A value system starts to shape in individual from an early age. The individual is influenced by his or her family, friends, school and the media. What is really meant here by 'influence' is the case of an individual adopting or not adopting various values. Values are thus very important in human life, because values are closely related to the preferences of individuals. In this sense, choices made by individuals are reflections of the values that they have (Harland \& Pickering, 2011).

However, defining the values that are believed to greatly influence human life simply as "tastes" may lead to an inadequate understanding of the concept of values, because the concept of values has more powerful and expansive meanings (Carr, 2011). Values is a wide concept involving basic beliefs and principles (Halstead \& Taylor, 2000). It also involves activities such as values education, moral education and citizenship education (Taylor, 1994; as cited in Thornberg, 2008).

The family constitutes the first step within values education. The family is the foundation of all upbringing and begins the educational process for an individual. Children start to see and learn how to speak and share emotions for the first time in the social world of the family. Children learn in a similar way, yet what they learn varies from family to family, because each family has a unique world-view and value system (Bozkurt, 2010).

The values-learning process, which starts informally in the family, is carried out formally in schools (Yazic1, 2006). Schools constitute the second step of the values-learning process. In terms of values education, values are taught in schools in two ways: theoretically and practically. Schools and teachers have a great practical influence on children in terms of development of values, followed by family, media and peer group. Schools are also the places where the values of the society are theoretically represented and reflected. The existence and development of values are thus closely related to schools. From this perspective, schools have an important role in ensuring that values continue their existence (Halstead, 2005).

Both the family and the school make important contributions to the education of individuals. Cooperation between family and school is considered to be important in students' academic, social and personal development (Özeke Kocabaş, 2006). There are several studies in Turkey highlighting the importance of and recommending cooperation between the family and school (Yazıc1, 2006; Yiğittir \& Öcal, 2010; Çelenk, 2003; Çakmak Güleç \& Genç, 2010). 
For a system to function well, each element composing the system must play its part (Kahyaoğlu \& Yangın, 2007). It has been suggested in certain studies that the family has as much influence as the school and teachers in the education of a student (Lovat, 2009; Kong \& Li, 2009; DeCastro-Ambrosetti \& Cho, 2005). An individual's education is thus not only up to the school or family solely. Rather, education is matter that requires a sharing of responsibilities (Şişman \& Taşdemir, 2008). When it comes to education, both family and school have various duties and responsibilities. For individuals to achieve the desired success and gain the desired values, there must be two-way communication, cooperation and coordination between family and school and this relationship must be built upon trust (Adams \& Christenson, 2000). In this context, cooperation between family and school is important in solution of problems encountered throughout a child's or teenager's educational life (Tay \& Yıldırım, 2009). Cooperation between family and school must be considered important not only for academic success and career choice, but for values education as well. Therefore, the family is important for both children's academic success and their gaining desired values. Goals set in relation to values can be achieved more quickly by winning the support of family.

Issues such as the importance of education, self-knowledge, confidence, hard work, professionalism, moral character, respect, the ability to communicate, well and the importance of human dignity, which are described in this study, and which the stud aimed to transform into behaviors, are actually universal human values. Some of these values are also among the values that the curriculum in Turkey aims to inculcate in students (Tonga \& Uslu, 2015).

\section{Method}

This study aims to carry out activities related to values and observe the effects of these activities on families and also to allow families to observe the results of their activities. It thus utilizes the action research model, which is a qualitative research method. Action research is defining a problem, taking action to solve the problem, observing how successful the attempt is and redoing if the attempt is unsuccessful; in short, learning by doing and experiencing (O'Brien, 2003; as cited in Aksoy, 2003).

\subsection{Stages of Action Research}

a. First of all, the families who would participate in the study were identified.

b. Families were given brief training about the study.

c. A specific "value" was determined for each month and activities related to this value were carried out.

d. The value for the month was determined taking into account families' opinions and needs.

e. A guide was prepared by the researcher relating to the value for the month.

f. The families held a family meeting on a certain day of the week.

g. The families came together with other families in their province on Friday.

h. A pilot application was carried out for three months to reveal shortcomings.

i. The families held meetings on a specific day of the week and provided the researcher with meeting reports at the end of the month.

The activities performed in this research can be summarized as follows. The purpose of the activities was to create an awareness in families in their everyday lives related to the value identified and help them transform these values into behavior. For this purpose, the families had a meeting on a specific day of the week and the participants shared observations that they identified during the week with each other. Thus, an attempt was made to create an awareness in participants regarding values. In these meetings, family members took on various assignments related to the value of the month. Then they shared their opinions and experiences of these assignments. For example, in the month when the value of "trust" was addressed, family members took on assignments related to being honest and shared their experiences of being honest with each other for a week.

The study started on an individual basis and each family member addressed values individually. Then the study continued in larger groups. Meetings were held both with specific families and with the participation of multiple families. During this process, the researcher participated in the educational program with his family and maintained his contact with other families and participated in their family meetings from time to time.

\subsection{Participants}

The participant group consisted of 13 families, all of whom were members of a non-governmental organization. A total of 51 individuals participated in the study, made up of 13 mothers, 13 fathers, 3 grandmothers, 3 
grandfathers, 6 pre-school children, 5 elementary school children and 8 high school students. The families were from 3 different cities in the Central Anatolia region of Turkey. They participated in the study voluntarily. Participants were between the ages of 3 and 70 , and among the adults their status varied from housewife to worker, teacher, judge, retiree, lawyer, civil servant and self-employment.

All of the participants were Muslim. In terms of ethnicity, most of the participants were Turkish. In addition, there were citizens of Kurdish origin among the participants. The participants had a certain preliminary knowledge about the values involved. Interviews conducted prior to the study revealed that the participants had knowledge and experience related to these values, because the participants were members of a non-governmental organization that places great importance on moral education. The participants expressed the sense that the problem that they had in relation to values was that these values were not generally transformed into behavior in family and society. Following this, a 24-month study on values education in the family was carried out with the participants. At the beginning of this study, no limit was considered on how long the values education activities would take. The activities started in October 2013 and are still being carried out as of January 2016, at the request of family members. This article evaluates the first 24 months only.

\subsection{Data Collection Tools}

Interviews, observation and document review were used in this research. A series of interviews related to values education was conducted with the participants. In addition, the researcher participated in some family meetings and took observation notes and performed document review using the meeting reports provided by the families.

As cited by Aksoy (2003) from various sources, interviews and observation are important data collection tools in action research. In this study, the researcher participated in the family meetings periodically and held family meetings with his own family as well. This allowed the researcher to empathize with the families participating in the study and better understand the process experienced by them.

\subsection{Data Collection, Analysis and Ethical Issues}

The research data consisted of meeting reports provided by the families on a monthly basis, interviews conducted with family members and observation reports. Some families prepared handwritten reports and sent the report to the researcher, whereas some families preferred to send the reports via e-mail.

In data analysis, I put all the data together as suggested by Creswell (2014). Then I read the data from beginning to end so that I would have an idea of the complete data. Then I read the texts again and encoded the data. After the encoding process, I prepared a list of codes and put the relevant codes together under certain themes. I did not use the participants' real names when giving examples from their opinions. I assigned code names to them and also specified their age and gender. (For example: Fatma, 15, f.).

\subsection{Validity and Reliability}

I used different data collection tools (Observation, interviews and document review). I communicated with participants during analyses, repeated their answers to them and asked their opinion about whether there was a misunderstanding or not. By doing so, I tried to clarify and combine their understanding of and with the statements made.

I participated in the program with my family (my wife and two children) and spent many hours with my family. We saw the other families constantly for almost two summers and went on vacation together.

In order to evaluate the analyses from a different perspective, I received support from a measurement and evaluation expert throughout the analysis process, had him analyze a certain part of the text, and compared it with my own analysis.

\subsection{The Researcher's Role}

I worked as a Social Studies teacher for five years. In this period, I had the opportunity to observe students and families closely. I also had the opportunity to explore families' views relating to values from different perspectives. In addition, I carried out values education activities with my students within the framework of the Social Studies course. In addition to these, I published articles on values and values education in peer-reviewed journals (Tonga \& Aksoy, 2014; Tonga \& Uslu, 2015; Tonga, 2015), presented declarations in international symposiums and served in regulatory boards of congresses on values education. Also, I have been a member of a non-governmental organization giving values and moral education for 15 years and still serve as an administrative board member and the education coordinator. I believe that these experiences gave me the required maturity and experience to conduct this research. 
In addition to these positive aspects, I would like to mention an aspect that could have had an impact on the study and caused bias and the measures I took in relation to this: I have had a close relationship with the families participating in this study. I believe that this close relationship could have caused bias in my observations. As suggested by Creswell (2014), I sought and received advice from 2 experts with published articles on values education in order to prevent this potentially negative aspect. I tried to adopt a critical approach towards my own observations by accepting their opinions and advice.

\subsection{Ethical Issues}

Some of the research data was posted on a website with the permission and at the request of the families. The families in the study do not feel uncomfortable with disclosing their identities, in contrast, they believe sharing good examples with others would be beneficial. Despite this fact, I have changed the names of the participants in this article. I also explained to the families that the study was on a voluntary basis and they could leave the study any time they wished.

\section{Results}

The findings of the study come from the data obtained from the meeting reports prepared by the families, face-to-face interviews and the observations of the researcher. The data collected was put together and the following themes emerged:

\section{1) Moral development}

\section{2) Development of communication skills}

\section{3) Religiousness}

In fact, the themes that emerged and the values needed by the participants ran parallel to each other. The values determined according to expert opinion and the request of the families were generally divided into two: "moral values" and "communication-related values". Values addressed in the study such as "trust", "sincerity", "honor", "pride" and "human dignity" can be considered as examples of moral values, whereas values such as "avoiding negative talk about others", "respecting others" "private lives", "empathy", "avoiding empty promises" can be given as examples of communication-related values. These values are also the values of Islam (Tonga, 2016).

\subsection{Moral Development}

On paper, the concept of morality is the most important concept in educational institutions in Turkey today. The specific goals of Turkish National Education involve teaching the values that a good person and a good citizen must have. However, when it comes to practice, it seems that educational organizations do not adequately support the moral development of individuals due to various reasons. When the data collected from the values education program were examined, it was seen that, first of all, families started to place higher importance on the concept of morality and had an increased awareness of their own moral development. The sub-themes constituting the theme of moral development can be placed under three headings: learning values and acquiring awareness, awareness and transforming values into behavior, and values and feelings.

\subsubsection{Learning Values and Acquiring Awareness}

The first sub-theme of the moral development theme is acquiring knowledge related to values. It was emphasized in the data collected from the families that correct knowledge had to be acquired in order to display the correct behavior. Below are sample sentences from the families:

"In this process, I have realized that I did not know the values that I thought I knew." (Turgut, 39, m.)

"Everybody talks about values, I do as well, but I have seen that there was a lot that I did not know about values." (Ahmet, 43, m.)

"With value education, we began to get to know ourselves and values that reflect people." (Melih, 45, m.)

"We had the opportunity to learn about family values." (Gazi, 46, m.)

"With monthly education studies, I tried to address a value that we need each month and acquire awareness." (Bilge, 29, f.)

"My awareness about values started to increase as I dwelt more on values and with self-education." (Birkan, 35, m.)

As mentioned above, the families primarily highlighted the importance of knowledge within the framework of values education. Fathers and mothers stated that learning about values themselves influenced their children positively in terms of values education and saw this as their responsibility: 
"As I tried to acquire the values that I want to see in my children, I realized that education and values are not only for children, but also for parents. For this reason, I understand the importance of having a preliminary knowledge about values." (Bilge, 29, f.)

"An informed values education given in the family has a great influence on children." (Hatice, 36, f.)

Some of the participants mentioned the questioning process that they went through both individually and as a family in order to acquire awareness about values. Below are some sample sentences:

"As family members, we asked this question to ourselves: What are the core values of our family? What do we care about in our family?" (Demir, 43, m.)

"One of the values that we dwelt upon was thought management. I'm almost 40 years old, I have realized that thoughts can be managed for the first time in my life. Now I can cope with negative thoughts if I have any." (Oğuzhan, 36, m.)

"I have started to ask more questions about values. For example, I try to find reasons why I should be honest." (Sevim, 40, f.)

\subsubsection{Awareness and Transforming Values into Behavior}

It was observed that awareness of values increased as the families started to take the program more seriously. As the awareness increased, values started to turn into behavior more frequently. Below are the opinions of the participants regarding this issue:

"People usually talk about values, but do not reflect them in their lives. How do I know? From myself. But now, I try to do what I preach to be good, beautiful and right. To know and to learn is to live." (Kamil, 33, m.)

"As my awareness about values increases, I try to avoid behavior that will make me feel ashamed." (Hanife, 14, f.)

"The point of knowledge is to apply it." (Melih, 45, m.)

Some participants questioned the concept of "development" and pointed out the importance of moral development, which they considered as a way of both material and spiritual development, as follows:

"I used to consider development as a material improvement or advancement in a career. My opinion changed after the values education. Now I know there is also moral development. Yes, now I understand that human morality develops and flourishes. Without moral education, it is not possible to live as a human.” (Kamil, 33, m.)

"I have realized that I was not giving the necessary attention to my inner world while trying to satisfy my earthly needs. Now I have not shopped for a year, I have realized that I have a lot of clothes. I have understood that you should just dress cleanly and tidily. In this sense, I have realized that excessive clothes' shopping is a waste and being wasteful is not fitting for a good man." (Hüseyin, 49, m.)

Concerning the importance of the mother's role in transforming values into behavior in children, a mother stated: "I have observed that actions are more important than words in a child's education." (Ayten, 46, f), whereas another mother pointed out that cooperation was shaped between family members while trying to turn values into behavior: "We have acquired common values and a common sense of morality in our family." (Gülin, 44, f.)

With the start of the transformation of values into behavior, the observations made by the participants began to become clear. Below are observations of some participants related to the transformation of values into behavior:

"It is very important to finish what you started. When I finish what I started, my confidence improves." (Ayla, 17, f.)

"A moral person does not lie. My confidence improves when I avoid lying." (Kadriye, 7, f.)

"I have noticed that being honest liberates the person." (Kemal, 41, m.)

\subsubsection{Values and Feelings}

Feelings have an important place in our lives. We perform jobs that we like happily, whereas a job that we do not like may make us unhappy in general. In this sense, the participants expressed what they felt as they transformed values into behavior as follows:

"The greatest freedom lies within the truth. Lies, on the other hand, bring embarrassment and shake confidence." (Özen, 36, f.)

"My teacher asked me question in school. I was not listening. I did not lie. I said, I did not listen, I was distracted. Telling the truth made me proud." (İlayda, 15, f.) 
"I have tried to transfer values into my everyday life by practicing them. My happiness increased as I observed them. I have understood that it is possible to be happy by enhancing your morality." (Turgut, 39, m)

"As I started to transform values into behavior within the scope of values education, my life gained a meaning. I started to feel happy as I became successful in this." (Ela, 20, f.)

Some participants stated the importance of how they felt about values before acting on them, as follows:

"I used get upset when I felt I was missing a quality. Now, I feel encouraged when I realize my shortcomings, because I feel strong enough to eliminate them." (Sevim, 40, f.)

"It is nice to transform a value into behavior, it is even nicer to have a happy inner world afterwards." (Bilge, 29, f.)

"It is easier to transform values into behavior when you have positive and loving feelings about them." (Ayla, 17, f.)

"It is nice that we are happy when we own something material. Similarly, it is nice that a value brings us happiness. For example, I like it when someone trusts me." (Kamil, 33, m.)

\subsection{Development of Communication Skills}

The second theme that emerged from the data analysis was communication. The sub-themes constituting the communication theme were "communication with self", "communication within the family" and "communication with others".

\subsubsection{Communication with Self}

We live in a world where people may be becoming more and more estranged from themselves as technology develops. Some individuals spend most of their time in a virtual environment communicating with others. Within the scope of the Family Education Program, the quality time that the participants spend with themselves increased and they had opportunities to get to know themselves better.

"We always think about a second person when we say communication. However, I have learned that there is also communication with myself. Now, I try to listen to my inner voice and my own thoughts, just like I listen to others." (Kamil, 33, m.)

"I used to consider human beings as their physical body. But now, I have realized that we are living beings in our bodies and our feelings, beliefs and ideas are just as important as our bodies." (Derya, 44, f.)

"One may get negative ideas during the day due to various reasons. Now I can turn my negative thoughts into positive thoughts with the thought management education given within the monthly education plans." (Oğuzhan, $36, \mathrm{~m}$.)

The participants pointed out the following in relation to their knowledge gained and increased self-awareness under the "communication with self" sub-theme.

"I've always wanted other to like me for my appearance. Now I want to be liked and accepted for my personality and morality. Because as I get to know myself, I have realized that one's inner world is very important." (Murat, $29, \mathrm{~m}$.)

"We always think of a second person when we say love. Is it not possible for one to love oneself? This is not selfishness. Love your country, love someone from the opposite sex, love the team that you support. But you must love yourself as well, I mean, a person must value himself and look after himself to be able to do so." (Bilge, 29, f.)

\subsubsection{Communication within the Family}

In the 21 st century, especially with the arrival of television and the internet, interpersonal communication seems to be reduced as well. This is evident within families too. It has been observed that amount of quality time people spend with their family has decreased. Families' coming together and communicating on certain days within the scope of this study had a positive effect. The participants pointed out that television in particular negatively influenced communication within the family. Below are some sample sentences:

"Soon after we began to hold family meetings, we stopped watching television. Now, family members spend much more time with each other." (Oğuzhan, 36, m.)

"Television used to be a part of our lives before this study. Sometimes we would argue with each other over a show. Now, we accept the fact that people are more important than television.” (Ayten, 46, m.) 
What is the most striking here is the data on how families feel about spending time with each other. The participants stated the following with regard to having increased quality time within the family:

"Once we addressed the same values as a family - I mean father, mother and children — we have become like schoolmates. Our support for each other increased. Our home has become a place where values are kept alive." (Zeliha, 50, m.)

"Family members, who cannot always make time for each other due to struggles of everyday life, meet on a specific day of the week and share their love, efforts, and excitement with each other. Communication within our family has become stronger by expressing our expectations of each other." (Demir, 43, m.)

"We have enjoyed being together as a family, sitting together and doing something together. We have realized how much we missed each other, even though we were living in the same house. We have learned to listen to each other." (Hüseyin, 49, m.)

"Communication within our family has improved in the last year and a half. Now we spend more time together." (Turgut, 39, m.)

"Until we started with this plan, we were like strangers in the same house. Everybody would live their own lives in their own room. Communication in our family has improved as we have started to spend more time using values education in the family. We have started to listen to and understand each other." (Erol, 53, m.)

The participants stated that they started to get together with family members and spend more time together:

"Our communication with each other has improved. Now family members are aware of each other's lives." (Gülin, 44, f.)

"As we have made an effort to adopt good values befitting to humans, our love and respect toward each other have increased." (Demir, 43, m.)

"Does a mother copy her child, learn something from her child? I know from experience, as I started to get to know our children seriously, I started to take their nice characteristics as an example and benefit from their life experiences." (Zeliha, 50, f.)

Some participants highlighted the importance of communication within family for implanting values in children and youth as follows:

"I believe behavior is just as important as words when it comes to communication within the family. Talking, giving good advice is the first stage. In the second stage, children must see these values in their father and mother. Values education in the family is even more effective like this." (Ayten, 46, f.)

"I have understood that the mother and father must have a good communication for peace to exist in a home and children to grow up as individuals with high morality and I have started to make an effort to improve my communication with my wife." (Turgut, 39, m.)

"It is possible to eliminate conflicts between generations when you live as a family based on values. Because if honesty is the issue, both the grandfather and the grandchild need it. Because no matter who you lie to, the other person will get upset and lose his trust in you. Can trust as a value only belong to a single generation?" (Demir, $43, \mathrm{~m}$.)

"When I reflected upon my life, I realized that my friends influence me greatly and give direction to my life. Therefore, families should address this issue with the proper language and take necessary measures to prevent their children becoming friends with immoral people. Of course, children will encounter with people with corrupt personalities. If we teach them what is good and what is bad, our children will not misjudge people and get hurt." (Murat, 29, m.)

\subsubsection{Contact with Others}

When communication is mentioned, people usually think of interaction with others. In this century, there is no course in Turkish education specifically for communication and the importance of communication is only touched on within certain courses. The participants stated that they improved their listening skills and established a more meaningful communication with others after being give assignments:

"One of the biggest gains from the family education has been related to communication. We have learned to leave our judgments aside and try to really understand others. We have realized the need for listening. Our tolerance improved as we listened to others." (Erol, 53, m.)

"As required by the principles of the program, I try to stay away from empty chatter and meaningless debates 
when talking to my friends. This way I do not disrespect anyone.” (İlayda, 15, f.)

Some participants highlighted the importance of moral values in interpersonal relationships:

"People fall out with each other due to cross-talks and gossip. Gossiping is actually a kind of corruption." (Ela, 20, f.)

"Arrogance is a bad quality in interpersonal communication. Similarly, I do not like selfish people either. Arrogant and selfish people are not loved and I try to avoid being arrogant and selfish." (Illayda, 15, f.)

\subsection{Religiousness}

In a general sense, Islam is a religion of values (Tonga, 2016). However, religion may be perceived only as the act worship due to misinformation from certain religious groups and leaders. When determining the values that they needed, the participants stated that they wanted to foster values such as trust, honor, human dignity, honesty and love for mothers, which are esteemed very highly by Islam, into their lives. In fact, these values are not only important in Islam. These are universal human values. Below are some associations established by the participants between Islam and values and the effects of religiousness on individuals:

"We will be good people by adhering to the orders and values of Allah" (Ayla, 17, f.)

"I want to be a moral person, as our Prophe was." (Halil, 25, m.)

"As my love for the Prophet grows, I become a reliable person." (Erdem, 43, m.)

"As my love for the Prophet grows, I become more tolerant." (Kamil, 33, m.)

"It is not possible to be a real Muslim without living by the values of Islam." (Nur, 40, f.)

"Our Prophet is proud of people who keep human values alive." (Azra, 34, f.)

"I am grateful for the beautiful values that Allah has given me." (Ayla, 17, f.)

When the examples given above are evaluated, it can be said that the participants considered the values of Islam to be general human values.

Below are some comments of the participants relating to the reflection of religious feelings in everyday life:

"My son starts his dinner by saying 'In the name of Allah' and he reminds us to do so as well." (Bilge, 29, f.)

"I take the Prophet as my model." (Azra, 34, f.)

"I am happy that I have a Prophet who guides me in life." (Selim, 22, m.)

"We try our best to give our children our sacred values." (Hatice, 36, f.)

"Allah does not like those who lie." (Kadriye, 7, f.)

"Allah likes those who share." (Sevgi, 8, f.)

\subsection{The Researcher's Observations}

First of all, I would like to express my happiness in being able to participate in the study with my family, seeing the development of my 7-year-old daughter and 4-year-old son and improving my communication and sharing with my wife. In this long process, I had the opportunity to be in the field, practice and observe for long hours. I noted most of this in a journal. I would like to summarize my findings and results as follows:

- Value is not a concept that can be learned on one's own. There are important details to consider in values education. In fact, these are details written in the literature, yet which are not considered when it comes to application, especially in Turkey. The first step in values education is to support the value held with actual knowledge. In other words, before expecting an individual to display a certain behavior desired by an educational activity, the value must be described and understood in detail. In addition, values are phenomena that become concrete when they are transformed into behavior. It seems quite difficult to determine whether the individual actually possesses a value if it is not transformed into behavior.

- I have observed that families with a sound foundation related to values education have an easier time transforming values into behavior and are more enthusiastic. I would therefore recommend that families be given an education such as this, free of charge.

- I cannot say that we have been $100 \%$ successful at the end of this program. There were families who started the program with great enthusiasm and left in the middle of the program. I was not able to interview them about why they left, but there were certain salient points. First of all, families in financial difficulties who were trying hard to make a living could not give the necessary attention to values education. Also, families who did not want 
to change the ways of life that they were used to were less willing to engage with new ideas.

- Families who knew each other and who met with each other occasionally influenced each other positively. Some families who left the program returned through the influence of other families. Families benefited from each other's energy and a synergy was created.

- Families who placed a great importance on children's education took values education more seriously. As can be seen in the statements of some of the mothers given above, some families gave their attention to values only because they wanted to see them in their children.

- Values education becomes more effective when considered as a whole, when it is carried out in an appropriate environment with the right guidance and written and visual material.

- I have observed that pre-school and elementary school children had a more positive approach toward values and adopted them more quickly. The group that gave us the most difficulty was the male high school students.

- Placing importance on spiritual values as well as material values, changing their value systems for the better is important in terms of developing good people and good citizens.

- One of the most important results of the research is that individuals gained self-awareness and increased their awareness about their inner world. Considering the shortcomings in the Turkish educational system relating to encouraging children and youth to get to know themselves, I believe that this study will contribute to the literature. Because students learn a lot of information in schools that they will not be able to use in everyday life, it was very important to obtain concrete results in terms of self-awareness, a much needed quality.

- I observed that families with young children in particular placed great importance on the values education program. Some participants asserted that the importance given to children whipped up their interest in values education: "It is not always possible to convince yourself about something, but when it comes to children, your will power increases because you know that your children look up to you."

- Another noteworthy detail that I noticed during the program was that families with a high religious disposition and religious sensitivity placed a greater importance on values education. The families indicated that this was because religion demanded moral individuals and values education was an appropriate practice with regard to this. In a sense, they believed that raising moral individuals was possible with a values education program such as ours. Expressions used by small children such as "Allah does not like those who lie", and "Allah does not like those who hurt others and punish them" were especially noteworthy examples.

\section{Discussion}

The results of this 24-month study, which aimed to apply a variety of activities and to families to help individuals transfer universal human values into their everyday lives and evaluate the results of these activities, can be evaluated as follows:

Three themes emerged from the resulting data: moral development, development of communication skills and religiousness. The themes which emerged and the values which seemed to be needed by the families ran parallel to each other.

The sub-themes constituting the moral development theme can be viewed under three headings: "learning values and acquiring awareness", "transforming awareness and the values into behavior", and "values and feelings". First of all, the participants made comments emphasizing the importance of learning values and their content comprehensively. The families believed that a correct theoretical framework was required for correct behavior to be displayed. The participants stated that they found meaning in their lives and had increased awareness relating to values as they transformed these values into behavior. In addition, they pointed out that a positive attitude toward values facilitated the transformation of values into behavior. As cited by Kağıtçıbaşı (2010) from various sources, high awareness strengthens the relationship between attitude and behavior. Also, Tay and Yildirım (2009) asked parents the five qualities that they wanted to see in their children and morality was among the first five qualities, which leads to the idea that parents wish to see their children develop morally. Similarly, as reported in the study conducted by Kuş, Merey and Karatekin (2015), parents stated that they did not make any special effort regarding the values education of their children, but wanted to teach them values in everyday life.

The first positive effect of this program is related to moral development. Although various activities are written into Turkish educational system, it is known that no great effort is made regarding moral education, apart from voluntary work of teachers and non-governmental organizations. It was seen in this study that people were interested in such a values education program and their attention was focused on the concept of morality. It was shown that values education in family could be successful when appropriate conditions are provided and the 
right steps are taken. A similar result was obtained in the study conducted by Kağıtçıbaşı, Bekman and Sunar (1993), who found that it was possible to improve the adapation of children to schooling and contribute to their healthy social and emotional development. This study also enabled people's attention to be directed at the concept of morality for a little while in the course of the their busy day-to-day lives.

The second theme was the development of communication skills. The sub-themes constituting the theme of communication were "communication with self", "communication within the family" and "communication with others". When communication is mentioned, people usually think of interaction with others. With this values education program, individuals acquired an awareness about themselves and started to care about their communication with themselves. Since ancient times, the imperative "Know yourself!" has been uttered by many, from ancient Greek philosophers to Far Eastern philosophers. Hence, it can be concluded that this program provided individuals the opportunity to engage in communication with themselves, which is one of the important conditions of getting to know oneself.

In addition, the participants stated that family meetings positively affected communication in the family and family members had the opportunity to get to know each other better. It was also observed that the other values determined and addressed positively affected communication with others as well.

It is known that some individuals spend much of their time in a virtual environment communicating with others or spend a large amount time on the internet given current developments in communication technologies. This is one of the reasons behind communication gaps within families. Television and computers may damage the communication and interaction within family. The ties of love, respect and trust in a family weaken due to watching television excessively and communication within family can be disrupted (Tarhan, 2014). In the study conducted by Kolay Akfert, Çakıcı and Çakıcı (2009) domestic problems were found to be important factors affecting smoking and the consumption of alcohol among young people. In this study, families enhanced the communication within family. It was stated by the participants that communication between family members who met on a specific day of the week and listened to each other respectfully was enhanced, and thus family ties were enhanced.

There is no specific course in the Turkish education system focusing directly on communication in elementary and middle schools. It was concluded from the answers of family members that this program helped the participants to establish a meaningful communication with others. Considering that being a good person and good citizen involves establishing meaningful and respectful communication with others, it is thought that individuals with well-developed value systems will contribute to the society. It has also been found, in the study conducted by Yildırım (2009) that Turkish form teachers believed that the inability of families to teach values negatively affected children.

The third theme in values education was religiousness. The participants associated values mostly with Islam and it was observed that participants with stronger religious beliefs were more enthusiastic about transforming values into behavior. The participants highlighted the importance of Islam's injunction for good behavior, prohibition of corruption, its advocating the principle of "do unto others as you would they should do unto you" and its belief in afterlife. Thus, it can be concluded as a result of this study that religion can assume an important role in keeping human values and virtues alive in the society. In a study conducted by Kaya and Aydın (2011) with 606 prospective teachers, a positive correlation was found between religiousness and moral maturity, which is consistent with findings of this study.

Two important findings were obtained regarding families who participated in the study, but were not able to achieve the desired results. Values education was not successful with families with financial problems and families who did not want to change their lifestyles and were not open to new ideas.

When the results of this study are evaluated in general, it is believed that the values determined could positively influence the development of democratic practices as well. This is because democracy is not only a form of government, but also a structure involving values such as human rights, freedom, equality, justice, promoting the sacredness of human existence and human dignity, and valuing humans (Duman, Yavuz, \& Karakaya, 2011). It is believed that positive results obtained from values education programs will contribute to educating individuals who believe in democracy, value humans and are able to increase the general level of peace and harmony in a society. 


\section{References}

Adams, K. S., \& Christenson, S. L. (2000). Trust and the family-school relationship examination of parent-teacher differences in elementary and secondary grades. Journal of School Psychology, 38(5), 477-497. http://dx.doi.org/10.1016/S0022-4405(00)00048-0

Akbaş, O. (2008). Değer eğitimi akımlarına genel bir bakış. Journal of Values Education, 6(16), 9-27.

Aksoy, N. (2003). Eylem araştırması: Eğitimsel uygulamaları iyileştirme ve değiştirmede kullanılacak bir yöntem. Kuram ve Uygulamada Eğitim Yönetimi, 9(4), 474-489.

Aladağ, S., \& Kuzgun, M. P. (2015). Sınıf öğretmeni adaylarının "değer" kavramına ilişkin metaforik algıları. Sakarya Üniversitesi Ĕ̈itim Fakültesi Dergisi, 29, 163-194.

Altınkurt, Y., \& Yılmaz, K. (2010). Değerlere göre yönetim ve örgütsel adalet ilişkisinin ortaöğretim okulu öğretmenlerinin algılarına göre incelenmesi. Kuram ve Uygulamada Eğitim Yönetimi, 16(4), 463-485.

Aspin, D. N. (2007). The Ontology of values and values education. In D. N. Aspin, \& J. D. Chapman (Eds.), Values Education and Lifelong Learning. Dordrecht: Springer. http://dx.doi.org/10.1007/978-1-4020-6184-4_1

Balcı, F. A., \& Yanpar Yelken, T. (2010). İlköğretim öğretmenlerinin “değer" kavramına yükledikleri anlamlar. Hacettepe Üniversitesi Eğitim Fakültesi Dergisi, 39, 81-90.

Balcı, F. A., \& Yelken, T. Y. (2013). İlköğretim sosyal bilgiler programında yer alan değerler ve değer eğitimi uygulamaları konusunda öğretmen görüşleri. Ahi Evran Üniversitesi Kırşehir Ĕ̆itim Fakültesi Dergisi, 14(1), $195-213$

Bills, L., \& Husbands, C. (2005). Values education in the mathematics classroom: Subject values, educational values and one teacher's articulation of her practice. Cambridge Journal of Education, 35(1), 7-18. http://dx.doi.org/10.1080/0305764042000332461

Bozkurt, V. (2010). Değişen dünyada sosyoloji. Bursa: Ekin Basım Yayın Dağııım.

Çakmak Güleç, H., \& Genç, S. Z. (2010). An evaluation of the interviews between teachers and parents about school and family cooperation in preschool education institutions. Education and Science, 35(155), 158-171.

Carr, D. (2011). Values, virtues and professional development in education and teaching. International Journal of Educational Research, 50, 171-176. http://dx.doi.org/10.1016/j.ijer.2011.07.004

Çelenk, S. (2003). Okul başarısının ön koşulu: Okul aile dayanışması. Illköğretim Online, 2(2), 28-34.

Çiftçi, T., \& Eser Ünaldı, Ü. (2014). Coğrafya öğretmenlerinin değer eğitiminin mevcut durumu ile ilgili görüş ve düşünceleri. Journal of World of Turks, 6(2), 81-99.

Cerit, Y. (2008). Öğretmen kavramı ile ilgili metaforlara ilişkin öğrenci, öğretmen ve yöneticilerin Görüşleri. Türk Eğitim Bilimleri Dergisi, 6(4), 693-712.

Choo, S. S. (2015). Towards a transnational model of critical values education: The case for literature education in $\begin{array}{lllll}\text { Singapore. Asia Pacific Journal of Education, 35(2), 226-240. } & \text {. }\end{array}$ http://dx.doi.org/10.1080/02188791.2014.922051

Cihan, N. (2014). Okullarda değerler eğitimi ve Türkiye'deki uygulamaya bir bakış. Electronic Turkish Studies, 9(2), 429-436. http://dx.doi.org/10.7827/TurkishStudies.6402

Creswell, J. W. (2014). Research design: Qualitative, quantitative, and mixed methods approaches. California: Sage publications.

DeCastro-Ambrosetti, D., \& Cho, G. (2005). Do parents value education? Teachers' perceptions of minority parents. Multicultural Education, 13(2), 44-46.

Demirhan İşan, C., \& Senemoğlu, N. (2009). Effectiveness of values education curriculum for fourth grades. Education and Science, 34(153), 1-14.

Deveci, H., \& Selanik Ay, T. (2009). İlköğretim öğrencilerinin günlüklerine göre günlük yaşamda değerler. The Journal of International Social Research, 2(6), 168-181.

Duman, T., Yavuz, N., \& Karakaya, N. (2011). Insan hakları ve demokrasi (Vatandaşlık bilgisi). Ankara: Data Yayınları.

Duru, A. (1975). Tanış. İstanbul: Özden Yayınları. 
Fidan, N. K. (2009). Öğretmen adaylarının değer öğretimine ilişkin görüşleri. Kuramsal Eğitimbilim Dergisi, 2(2), $1-18$.

Gömleksiz, M. N., \& Cüro, E. (2011). Sosyal Bilgiler dersi öğretim programında yer alan değerlere ilişkin öğrenci tutumlarının değerlendirilmesi. Uluslararası İnsan Bilimleri Dergisi, 8(1), 95-134.

Halstead, J. M., \& Taylor, M. J. (2000). Learning and teaching about values: A review of recent research. Cambridge Journal of Education, 30(2), 169-202. http://dx.doi.org/10.1080/713657146

Halstead, J. M. (2005). Values in education and education in Values. In J. M. Halstead, \& M. J. Taylor (Eds.), Values and values education in schools. The USA: Routlegde.

Harland, T., \& Pickering, N. (2011). Values in higher education teaching. Oxon: Routlegde.

Holden, C. (2000). Growing up today: Children talking about social issues. In M. Leicester, C. Modgil, \& S. Modgil (Eds.), Classroom issues: Practice, Pedagogy and Curriculum Education, Culture and Values (Vol. III). London: Falmer Press.

Kabapınar, Y. (2007). 1998 ve 2004 öğretim programlarına göre yazılmış hayat bilgisi ve sosyal bilgiler ders kitaplarında sosyal olay ve değerlerin sunumu: İşlev ve nitelik açısından farklı bir noktaya geldik mi? Marmara Üniversitesi Ĕgitim Bilimleri Dergisi, 25, 109-127.

Kağıtçıbaşı, Ç. (2010). Günümüzde insan ve insanlar. İstanbul: Evrim Yayınları.

Kağıtçıbaşı, Ç., Bekman, S., \& Sunar, D. (1993). Başarı ailede başlar. İstanbul: Ya-Pa Yayın Pazarlama.

Kahyaoğlu, M., \& Yangın, S. (2007). İlköğretim öğretmen adaylarının mesleki özyeterliklerine ilişkin görüşleri. Kastamonu Ĕ̈itim Dergisi, 15(1), 73-84.

Kaya, M., \& Aydın, C. (2011). Üniversite öğrencilerinin dini inanç ile ahlaki olgunluk düzeyleri arasındaki ilişkinin incelenmesi. Ondokuz Mayıs Üniversitesi İlahiyat Fakültesi Dergisi, 30, 15-42.

Keskin, H. K., \& Yapıcı, Ş. (2008). Başarılı ve başarısız öğrencilerin kişilik özellikleri ile ilgili öğretmen ve veli görüşleri. Kuramsal Eğitimbilim Dergisi, 1(1), 20-32.

Kolay Akfert, S., Çakıcı, E., \& Çakıcı, M. (2009). Üniversite öğrencilerinde sigara-alkol kullanımı ve aile sorunları ile ilişkisi. Anatolian Journal of Psychiatry, 10, 40-47.

Kong, S. C., \& Li, K. M. (2009). Collaboration between school and parents to foster information literacy: Learning in the information society. Computers \& Education, 52(2), 275-282. http://dx.doi.org/10.1016/j.compedu.2008.08.004

Kulaksızoğlu, A., \& Dilmaç, B. (2000). İnsani değerler eğitimi programı. M. Ü. Atatürk Eğitim Fakültesi Eğitim Bilimleri Dergisi, 12, 199-208.

Kuş, Z., Merey, Z., \& Karatekin, K. (2015). The value preferences of the parents in Turkey towards their children. Journal of Social Science Education, 14(1), 74-85.

Law, D. (2013). Educational values and the value of higher education. Perspectives: Policy and Practice in Higher Education, 17(3), 81-83.

Lovat, T. (2009). Values education and quality teaching: Two sides of the learning coin. In T. Lovat, \& R. Toomey (Eds.), Values education and quality teaching. Dordrecht: Springer. http://dx.doi.org/10.1007/978-1-4020-9962-5

Lovat, T. J., \& Clement, N. D. (2008). The pedagogical imperative of values education. Journal of Beliefs, 29(3), 273-285. http://dx.doi.org/10.1080/13617670802465821

Moosmayer, D. C., \& Siems, F. U. (2012). Values education and student satisfaction: German business students' perceptions of universities' value influences. Journal of Marketing for Higher Education, 22(2), 257-272. http://dx.doi.org/10.1080/08841241.2012.746254

Moreland, R. L., \& Levine, J. M. (1982). Socialization in small groups: Temporal changes in individual-group relations. In L. Berkowitz (Ed.), Advances in experimental social psychology (Vol. 15). London: Academic Press.

Oğuz, E. (2012). Öğretmen adaylarının değerler ve değerler eğitimine ilişkin görüşleri. Kuram ve Uygulamada Eğitim Bilimleri-Değerler Eğitimi Sempozyumu Ek Özel Saylsı, 12(2), 1309-1325.

Özeke Kocabaş, E. (2006). Eğitim sürecinde aile katılımı: Dünyada ve Türkiye'deki çalışmalar. Türk Psikolojik Danışma ve Rehberlik Dergisi, 3(26), 143-153. 
Özkan, R. (2010). Türk eğitim sisteminde himayeci değerler: İlköğretim ders kitapları örneği. International Journal of Human Sciences, 7(1), 1124-1141.

Şişman, M., \& Taşdemir, İ. (2008). Türk eğitim sistemi ve okul yönetimi. Ankara: Pegem Akademi.

Sundström, A., \& Wolming, S. (2014). Swedish student police officers' job values and relationships with gender and educational background. Police Practice and Research, 15(1), 35-47. http://dx.doi.org/10.1080/15614263.2013.815385

Tahiroğlu, M., Yıldırım, T., \& Çetin, T. (2010). Değer eğitimi yöntemlerine uygun geliştirilen Çevre eğitimi etkinliğinin, ilköğretim 7. sınıf öğrencilerinin çevreye ilişkin tutumlarina etkisi. Selçuk Üniversitesi Ahmet Keleşoğlu Eğitim Fakültesi Dergisi, 30, 231-248.

Tarhan, N. (2014). Aile Okulu. İstanbul: Timaş Yayınları.

Tay, B., \& Yıldırım, B. (2009). Parents' views regarding the values aimed to be taught in social studies lessons. Educational Sciences: Theory \& Practice, 9(3), 1499-1542.

Thomson, E., \& Bernhardt, E. (2010). Education, Values, and cohabitation in Sweden. Marriage \& Family Review, 46(1-2), 1-21. http://dx.doi.org/10.1080/01494921003648431

Thornberg, R. (2008). Thelack of professional knowledge in values education. Teaching and Teacher Education, 24, 1791-1798. http://dx.doi.org/10.1016/j.tate.2008.04.004

Thornberg, R., \& Oğuz, E. (2013). Teachers' views on values education: A qualitative study in Sweden and Turkey. International Journal of Educational Research, 59, 49-56. http://dx.doi.org/10.1016/j.ijer.2013.03.005

Tonga, D., \& Uslu, S. (2015). Sosyal Bilgiler Dersinde Kazanım-Değer İlişkisi. Ahi Evran Üniversitesi Kırşehir Eğitim Fakültesi Dergisi, 16(1), 91-110.

Tonga, D. (2015). Eğitimde tartışılması ve çözülmesi gereken güncel sorunlar: Şike, kopya, torpil ve doping. Türkiye Sosyal Araştırmalar dergisi, 19(1), 313-328.

Tonga, D. (2016). Social studies education and Islam in Turkey. Internatioanal Online Journal of Educational Science, 5(2), 24-37. http://dx.doi.org/10.15345/iojes.2016.01.009

Tonga, D., \& Aksoy, B. (2014). Evaluation of the patriotic attitudes of the prospective teachers according to various variables. International Journal of Academic Research Part B, 6(1), 172-178. http://dx.doi.org/10.7813/2075-4124.2014/6-1/B.24

Webster, R. S. (2010). Does the Australian national framework for values education stifle an education for world $\begin{array}{llll}\text { peace. Educational Philosophy and Theory, 42(4), 462-475. } & \text { and }\end{array}$ http://dx.doi.org/10.1111/j.1469-5812.2008.00485.x

Yaman, H., \& Çolak, S. (2009). İlköğretim ikinci kademe Türkçe ders kitaplarinda yer alan değerler. Journal of Values Education, 7(18), 107-120.

Yazar, T. (2012). Öğretmen adaylarının değerler hakkındaki görüşleri. Pegem Eğitim ve Öğretim Dergisi, 2(1), 61-68.

Yazıcı, K. (2006). Değerler eğitimine genel bir bakış. Türklük Bilimi Araştırmaları Dergisi, 19, 499-522.

Yeşil, R., \& Aydın, D. (2007). Demokratik değerlerin eğitiminde yöntem ve zamanlama. Türkiye Sosyal Araştırmalar Dergisi, 11(2), 65-84.

Yiğittir, S., \& Öcal, A. (2010). İlköğretim 6. sınıf öğrencilerinin değer yönelimleri. Selçuk Üniversitesi Sosyal Bilimler Enstitüsü Dergisi, 24, 407-116.

Yıldırım, K. (2009). Values education experiences of Turkish class teachers: A Phenomonological approach. Eurasian Journal of Educational Research, 35, 165-184.

Yılmaz, K. (2007). İlköğretim okulu yönetici ve öğretmenlerinin değerlere göre yönetim ile ilgili görüşleri. Kuram ve Uygulamada Ë̆itim Yönetimi, 13(4), 639-664.

\section{Copyrights}

Copyright for this article is retained by the author(s), with first publication rights granted to the journal.

This is an open-access article distributed under the terms and conditions of the Creative Commons Attribution license (http://creativecommons.org/licenses/by/3.0/). 